\title{
Impact of Drought and Temperature on Growth and Leaf Gas Exchange of Six Bedding Plant Species Under Greenhouse Conditions
}

\author{
Genhua Niu ${ }^{1}$ and Denise S. Rodriguez \\ Texas A\&M University, Agricultural Research and Extension Center, 1380 \\ A\&M Circle, El Paso, TX 79927 \\ Yin-Tung Wang \\ Texas A\&M University, Agricultural Research and Extension Center, 2415 \\ East Highway 83, Weslaco, TX 78596
}

Additional index words. Agastache urticifolia, Capsicum annuum, Catharanthus roseus, Cineraria maritima, environmental stress, Plumbago auriculata, Petunia $\times$ hybrida

\begin{abstract}
The effect of drought on the growth and gas exchange of six bedding plant species-agastache [Agastache urticifolia (Benth.) O. Kuntze 'Honeybee Blue'], dusty miller (Cineraria maritima $\mathbf{L}$. 'Silverdusty'), petunia (Petunia $\times$ hybrida 'Wave Purple'), plumbago (Plumbago auriculata Lam. 'Escapade'), ornamental pepper (Capsicum annuum L. 'Black Pearl'), and vinca [Catharanthus roseus (L.) G. Don 'Titan']—was quantified under greenhouse conditions. Seeds were sown in January and seedlings were grown in the greenhouse until 18 Apr., when two irrigation treatments-drought (D, $\approx \mathbf{1 8 \%}$ volumetric moisture content at reirrigation) and control $(\mathrm{C}, \approx \mathbf{2 5 \%}$ volumetric moisture content at reirrigation)-were initiated. Leaf net photosynthetic rate $\left(P_{n}\right)$, stomatal conductance $\left(\mathrm{g}_{\mathrm{s}}\right)$, and transpiration $(\mathrm{E})$ were determined in response to a range of substrate moisture content (from $\approx 5 \%$ to $30 \%$ by volume) and temperature (from $20{ }^{\circ} \mathrm{C}$ to $40^{\circ} \mathrm{C}$ ). Dry weight of agastache, ornamental pepper, and vinca was unaffected by drought, whereas that of other species was reduced. Leaf area of plumbago and height of plumbago and vinca were reduced by drought. As substrate moisture content decreased from $25 \%$ to $10 \%, P_{n}, E$, and $g_{s}$ decreased linearly in all species except petunia and plumbago. Leaf net photosynthetic rate of all species declined as leaf temperature increased from $20{ }^{\circ} \mathrm{C}$ to $40{ }^{\circ} \mathrm{C}$. In contrast, $\mathrm{E}$ of all species, except petunia, increased as temperature increased. Transpiration rate of petunia increased as temperature increased from $20{ }^{\circ} \mathrm{C}$ to $30{ }^{\circ} \mathrm{C}$, and then decreased between $30{ }^{\circ} \mathrm{C}$ and $40{ }^{\circ} \mathrm{C}$. Although petunia had the highest $P_{n}$ among the tested species, its $P_{n}$ and $g_{s}$ declined more rapidly compared with the other species as temperature increased from $20{ }^{\circ} \mathrm{C}$ to $40{ }^{\circ} \mathrm{C}$ or as substrate moisture content decreased, indicating that petunia was most sensitive to high temperature and drought.
\end{abstract}

Bedding plant production is the fastestgrowing segment in the floriculture industry in the United States. The wholesale value for bedding and garden plants in 2004 was $\$ 2.53$ billion, a $4 \%$ increase from the previous year (U.S. Department of Agriculture, 2005). Despite their economic importance, little scientific information exists on bedding plants in response to drought and heat stresses. The number of varieties of bedding plants for landscapes in hot, dry regions seems limited, possibly because of the lack of reliable information on species and cultivars that toler-

Received for publication 8 May 2006. Accepted for publication 22 June 2006. This project was supported in part by the Cooperative State Research, Education and Extension Service, U.S. Department of Agriculture under agreement no. 2005-3446115661. We thank PanAmerican Seed Co. for providing seeds.

${ }^{1}$ To whom reprint requests should be addressed; e-mailgniu@ag.tamu.edu. ate the extended periods of extreme summer heat and drought stress. Understanding the response to drought stress among bedding plant species and cultivars is important for selection of plant materials for improved landscape performance and for expanded use of these plants in areas where they are not widely used.

Photosynthesis is the primary process for plant biomass production and is one of the most sensitive physiological processes to environmental stresses (Hsiao and Acevedo, 1974; Huang, 2004). Consequently, the ability to maintain a reasonable rate of photosynthesis under stressful conditions can be a good indicator of a plant's adaptability. Considerable variations in gas exchange in response to temperature among genotypes and provenance have been reported for holly (Ilex spp.) (Ranney and Ruter, 1997), rhododendron (Rhododendron hyperythrum Hayata) (Ranney et al., 1995), and raspberry (Rubus idaeus L.) (Stafne et al., 2000), and their characteristics of gas exchange can be used for selection of heat-tolerant genotypes and cultivars. Numerous studies have been conducted on physiological responses to environmental stresses (temperature and soil moisture) on many agronomic crops (Ennahli and Earl, 2005; Huang and Jiang, 2001). However, no such information is available for bedding plants.

Drought stress reduces photosynthetic rate and growth in many plant species (Abrams et al., 1990; Anyia and Herzog, 2004; Epron et al., 1992). Drought also reduces elongation or growth of greenhouse ornamentals, and mild drought stress is commonly used to keep plants compact (Ball, 1998; Burnett et al., 2005). The natural hot and dry environment may eliminate or reduce the need for plant growth regulators, which are frequently applied to many ornamental plants in greenhouses and landscapes to suppress growth of fast-growing plants such as petunia (Ball, 1998).

The following six bedding plant species and cultivars were selected for this study: agastache 'Honeybee Blue', dusty miller 'Silverdusty', petunia 'Wave Purple', plumbago 'Escapade', ornamental pepper 'Black Pearl', and vinca 'Titan'. These species, or strictly the cultivars of these species, are potentially drought and heat tolerant (B. Liu, PanAmerican Seed Co., pers. comm., Oct., 2004). The objectives of this study were to characterize the response of gas exchange of these bedding plants, grown in the greenhouse, to a range of substrate moisture content and temperature, and to quantify the effect of mild drought stress on growth and morphology of these bedding plants.

\section{Materials and Methods}

Plant materials and cultural conditions

Seeds of agastache 'Honeybee Blue', dusty miller 'Silverdusty', petunia 'Wave Purple', plumbago 'Escapade', ornamental pepper 'Black Pearl', and vinca 'Titan' were sown in 406-cell trays filled with a substrate mix containing fine Canadian sphagnum peat, fine perlite, gypsum, powdered dolomitic limestone, wetting agent, and a low fertilizer charge (Sunshine mix no. 5; SunGro Hort., Bellevue, Wash.) on 25 Jan. 2004, transplanted to 126-cell trays on 2 Mar. 2004 , and grown in a fiberglass greenhouse. Seedlings, except petunia, were transplanted in mid Mar. to $500-\mathrm{mL}$ plastic containers filled with a similar substrate but with course perlite (Sunshine mix no. 4, SunGro Hort.). Petunia plants were transplanted to $2.6-\mathrm{L}$ containers because of their rapid growth. Before initiating the treatments, plants were subirrigated with a nutrient solution containing $0.5 \mathrm{~g} \cdot \mathrm{L}^{-1}$ of $20 \mathrm{~N}-8.6 \mathrm{P}-16.7 \mathrm{~K}$ (Peters 20-20-20; J.R. Peters, Allentown, Pa.). The average actual greenhouse environmental conditions during the experimental period were maintained as follows: day temperature at $25 \pm 3{ }^{\circ} \mathrm{C}$ and night at $20 \pm 2{ }^{\circ} \mathrm{C}$, day relative humidity at $30 \pm 5 \%$ and night at $45 \pm$ $5 \%$, and daily light integral $(P A R)$ was measured at $16 \pm 3 \mathrm{~mol} \cdot \mathrm{m}^{-2} \cdot \mathrm{d}^{-1}$. Shade cloth 
(25\% light exclusion) was installed in mid Apr. on top of the greenhouse roof. The temperatures were measured by thermocouples (copper and constantan) and photosynthetic photon flux $(P P F)$ was measured by a quantum sensor (model QSO-SUN; Apogee Instruments, Logan, Utah) every $10 \mathrm{~s}$, and the hourly averages were recorded by a $21 \mathrm{X}$ datalogger (Campbell Scientific, Logan, Utah). The maximum $P P F$ during the experimental period was $1000 \mu \mathrm{mol} \cdot \mathrm{m}^{-2} \cdot \mathrm{s}^{-1}$ or 800 $\mu \mathrm{mol} \cdot \mathrm{m}^{-2} \cdot \mathrm{s}^{-1}$ before or after the installation of shade cloth.

\section{Drought treatment}

Twenty-four plants per species were assigned to two irrigation regimens, drought and control, which were initiated on 18 Apr. Drought was achieved by withholding irrigation to reach target container weights. Because water use of one species was different from another, 12 plants of the same species were placed in one plastic flat $(27 \times 54 \times$ $6 \mathrm{~cm}$ ) and subirrigated when the combined weight of the flat and the plants reached a target value, which was predetermined to allow for the majority of the plants to exhibit signs of slight drought stress (mild wilting) in the drought group and no stress sign for the control plants. Specifically, plants were checked twice a day and reirrigated when $\approx 25 \%$ or $18 \%$ of their substrate volumetric moisture content was reached, for control or drought treatment respectively. Volumetric substrate moisture content was estimated as follows: [(gram fresh weight of the medium gram dry weight of the medium)/milliliter volume of the medium] $\times 100 \%$. The specific weights of flats for the corresponding $25 \%$ and $18 \%$ substrate contents were predetermined with consideration of fresh weight increases of the plants over time. Flats were rotated on the greenhouse benches whenever irrigated to minimize the differences in microenvironment. Also, plant positions were rotated within each flat after irrigation. Upon ending the irrigation treatment on 31 May, four randomly selected plants were destructively harvested to determine plant height, leaf area, and fresh and dry weights. Leaf area was measured using a leaf area meter (LI3100: LI-COR, Lincoln, Nebr.).

\section{Leaf gas exchange in response to substrate moisture content}

The plants used to measure net photosynthesis $\left(\mathrm{P}_{\mathrm{n}}\right)$, leaf transpiration $(\mathrm{E})$, and stomatal conductance $\left(g_{s}\right)$ were part of a separate group of plants grown in the same greenhouse. Before the measurement, all plants were kept well watered. To create various substrate moisture levels, irrigation was withheld for various periods of time. To determine the substrate moisture level immediately after the measurement, the volume and fresh weight of the medium were recorded. Dry weight of the medium was determined after oven drying at $80{ }^{\circ} \mathrm{C}$ for $48 \mathrm{~h}$. The volumetric substrate moisture content was then determined as mentioned previously. At the time of measurement, agastache, dusty miller, plumbago, and ornamental pepper were at vegetative stages whereas other species were flowering.

Gas exchange was measured by placing the most recently matured leaf in the cuvette of a portable gas exchange system (CIRAS-2; PP Systems, Amesbury, Mass.). The environmental conditions in the cuvette were controlled at a leaf temperature of $25{ }^{\circ} \mathrm{C}$, $P P F$ at $1000 \mu \mathrm{mol} \cdot \mathrm{m}^{-2} \cdot \mathrm{s}^{-1}$, and $\mathrm{CO}_{2}$ concentration at $375 \mu \mathrm{mol} \cdot \mathrm{mol}^{-1}$. Data were recorded when the environmental conditions and gas exchange parameters in the cuvette had become stable, which usually took 3 to $10 \mathrm{~min}$, depending on the species. These measurements were taken between $0800 \mathrm{HR}$ and $1400 \mathrm{HR}$ from early May through early June on 6 to 16 plants per species, depending on availability at particular substrate moisture levels. Because regression analysis was used, the differences in the number of plants being measured among species should not affect the statistical results.

\section{Leaf gas exchange in response to temperature}

The temperature responses of $\mathrm{P}_{\mathrm{n}}, \mathrm{E}$, and $\mathrm{g}_{\mathrm{s}}$ of well-watered plants were determined by placing the most recently matured leaf in the cuvette of the same portable gas exchange system. Temperature in the cuvette was raised from 20 to $40{ }^{\circ} \mathrm{C}$ in increments of $5{ }^{\circ} \mathrm{C}$. Other environmental conditions in the cuvette were kept the same as those mentioned earlier. Data were recorded when the environmental conditions and gas exchange parameters had become stable in the cuvette. Four plants were measured at each temperature per species. Because the instrument system does not have the capability to increase humidity in the cuvette, controlling vapor pressure deficit (VPD) at similar levels for a temperature range of 20 to $40{ }^{\circ} \mathrm{C}$ was impossible. However, at the same temperature, similar VPDs were maintained for all species.

\section{Data analysis}

The significance of drought stress on plant growth and morphology (leaf area and height) was analyzed using a $t$ test. Gas exchange parameters were plotted against leaf temperature or substrate volumetric moisture content. Linear or quadratic regression was conducted and the significance was analyzed using PROC REG (SAS Institute, Cary, N.C.).

\section{Results and Discussion}

\section{Effect of drought on plant growth and morphology}

Dry weight of agastache, ornamental pepper, and vinca did not change, whereas that of dusty miller, petunia, and plumbago was significantly reduced by the drought stress (Table 1). Drought stress resulted in reduced leaf area in plumbago but did not affect that of the other species. Plumbago and vinca plants were shorter in the drought treatment than the control plants. Height of the other species was unaffected by drought stress. The height of petunia plants was not measured because they grew horizontally.

Generally, the differences in growth and morphology were small because the two irrigation treatments did not differ substantially. At $18 \%$ substrate moisture content, gas exchange $\left(P_{n}, g_{s}, E\right)$ was significantly decreased (Figs. 1 and 2). Because the weights of the flats were checked twice a day for water stress, plants were grown for most of the time at nonstressed substrate moisture contents, even for the plants in the drought group that were reirrigated at $18 \%$ medium moisture content. The plants were irrigated about every 2 to $3 \mathrm{~d}$ for the control and 3 to $5 \mathrm{~d}$ for the drought group, depending on species, growing stage (plant size), and climatic conditions.

It was reported that growth of Salvia splendens F. Sellow ex Roem. \& Schult. was positively correlated with pot size (van Iersel, 1997). The small volume of containers $(500 \mathrm{~mL})$ may have limited the growth of agastache, ornamental pepper, and vinca, which may reduce the effect of drought stress on growth. The shorter period of treatment (6 weeks) may also limit the difference between the two treatments.

\section{Leaf gas exchange in response to substrate moisture content}

As substrate moisture content decreased, $\mathrm{P}_{\mathrm{n}}, \mathrm{g}_{\mathrm{s}}$, and E decreased linearly, except for those of petunia and plumbago (Fig. 1).

Table 1. Effect of irrigation treatments, control (C, substrate moisture content at $\approx 25 \%$ at reirrigation), and drought $(\mathrm{D}$, substrate moisture content at $\approx 18 \%$ at reirrigation) in the greenhouse on shoot dry weight, leaf area, and height of six bedding plants: agastache (Agastache urticifolia 'Honeybee Blue'), dusty miller (Cineraria maritima 'Silverdusty'), petunia (Petunia $\times$ hybrida 'Wave Purple'), plumbago (Plumbago auriculata 'Escapade'), ornamental pepper (Capsicum annuum 'Black Pearl'), and vinca (Catharanthus roseus 'Titan').

\begin{tabular}{|c|c|c|c|c|c|c|}
\hline \multirow[b]{2}{*}{ Species } & \multicolumn{2}{|c|}{ Dry wt (g) } & \multicolumn{2}{|c|}{ Leaf area $\left(\mathrm{cm}^{2}\right)$} & \multicolumn{2}{|c|}{$\mathrm{Ht}(\mathrm{cm})$} \\
\hline & $\mathrm{C}$ & $\mathrm{D}$ & $\mathrm{C}$ & $\mathrm{D}$ & $\mathrm{C}$ & $\mathrm{D}$ \\
\hline Agastache & 2.3 & 1.7 & 481 & 342 & 10.7 & 7.6 \\
\hline Dusty miller & $3.4^{*}$ & 2.5 & 242 & 209 & 5.3 & 4.9 \\
\hline Petunia & $26.0^{* *}$ & 18.0 & 1758 & 1183 & $-^{z}$ & - \\
\hline Plumbago & $3.0^{*}$ & 2.3 & $294^{* *}$ & 220 & $28.1^{* * *}$ & 21.8 \\
\hline Ornamental pepper & 4.2 & 4.0 & 545 & 490 & 25.6 & 26.5 \\
\hline Vinca & 3.0 & 2.8 & 552 & 499 & $13.1^{* * *}$ & 11.3 \\
\hline
\end{tabular}

${ }^{\mathrm{z}}$ Not measured.

*,** Significant at $P \leq 0.05$ and $P \leq 0.01$, respectively, by $t$ test. 

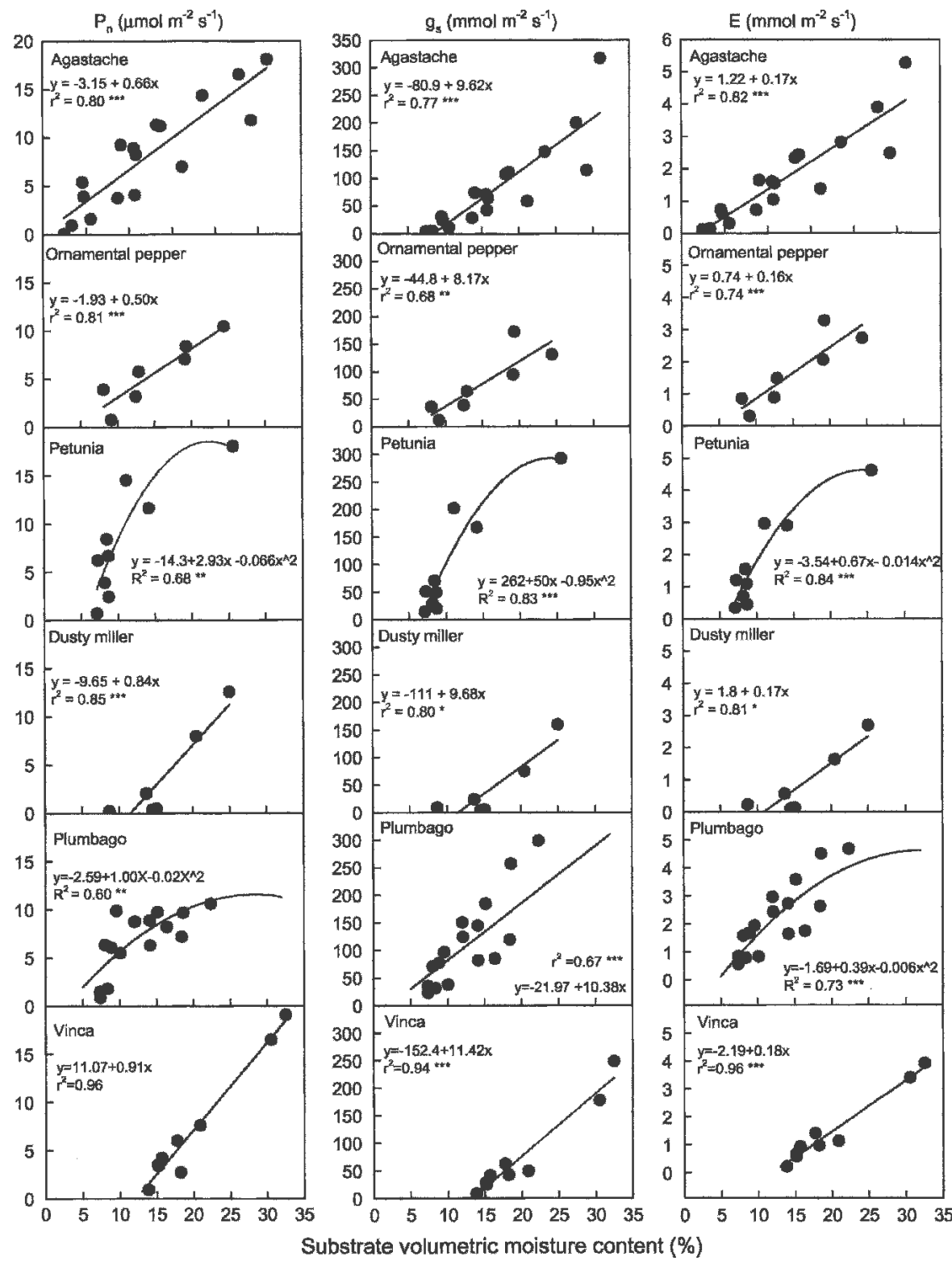

Fig. 1. Leaf net photosynthetic rate $\left(\mathrm{P}_{\mathrm{n}}\right)$, stomatal conductance $\left(\mathrm{g}_{\mathrm{s}}\right)$, and transpiration $(\mathrm{E})$ of agastache (Agastache urticifolia 'Honeybee Blue'), dusty miller (Cineraria maritima 'Silverdusty'), petunia (Petunia $\times$ hybrida 'Wave Purple'), plumbago (Plumbago auriculata 'Escapade'), ornamental pepper (Capsicum annuum 'Black Pearl'), and vinca (Catharanthus roseus 'Titan') in response to decreasing substrate moisture content. In each graph, $*, * *$, and $* * *$ indicate significance of the linear or quadratic regression at $P=0.05,0.01$, or 0.001 respectively.

Between $5 \%$ and $15 \%$ substrate moisture content, $\mathrm{P}_{\mathrm{n}}, \mathrm{g}_{\mathrm{s}}$, and $\mathrm{E}$ of petunia decreased linearly with substrate moisture content. However, the decreasing slopes for $\mathrm{P}_{\mathrm{n}}, \mathrm{g}_{\mathrm{s}}$, and $\mathrm{E}$ of petunia with substrate moisture content were much sharper than those of other species. Among the other species, the decreases in $\mathrm{P}_{\mathrm{n}}, \mathrm{g}_{\mathrm{s}}$, and $\mathrm{E}$ of ornamental pepper were the slowest (smallest slope), whereas those of vinca tended to decrease more rapidly.

\section{Leaf gas exchanges in response \\ to temperature}

Leaf net photosynthetic rate of all species declined as leaf temperature increased from 20 to $40{ }^{\circ} \mathrm{C}$ (Fig. 2). The maximum $\mathrm{P}_{\mathrm{n}}$ for ornamental pepper at $20{ }^{\circ} \mathrm{C}$ and $25^{\circ} \mathrm{C}$ was about $50 \%$ lower than that of agastache. However, the percentage decrease in $\mathrm{P}_{\mathrm{n}}$ for ornamental pepper as temperature increased from 20 to $40{ }^{\circ} \mathrm{C}$ was smaller than that of agastache. There was no correlation between $\mathrm{g}_{\mathrm{s}}$ and temperature for agastache. Stomatal conductance of ornamental pepper decreased gradually as temperature increased. Transpiration rate of all species increased as temperature increased, except for $\mathrm{E}$ of petunia, which reached a peak at $30{ }^{\circ} \mathrm{C}$, and then declined thereafter. This was because VPD increased with temperature. Vapor pressure deficit was $1.2 \mathrm{kPa}$ at $20{ }^{\circ} \mathrm{C}$ whereas it increased to $5.4 \mathrm{kPa}$ at $40{ }^{\circ} \mathrm{C}$.
Dusty miller had similar $\mathrm{P}_{\mathrm{n}}$ at temperatures of 20 to $30{ }^{\circ} \mathrm{C}$, and $\mathrm{P}_{\mathrm{n}}$ decreased as temperature further increased. Stomatal conductance of dusty miller in response to temperature was different from that of other species. There were no significant differences in $g_{s}$ as temperature increased from 20 to $35{ }^{\circ} \mathrm{C}$. However, $g_{s}$ at $40{ }^{\circ} \mathrm{C}$ was almost double that at lower temperatures. Transpiration rate increased sharply as temperature increased from 20 to $40{ }^{\circ} \mathrm{C}$. Also, it took longer for this species to reach stable conditions of $\mathrm{P}_{\mathrm{n}}, \mathrm{g}_{\mathrm{s}}$, and $\mathrm{E}$ during the measurement, compared with the other species.

Petunia had the highest maximum $P_{n}$, followed by agastache and vinca. But there were larger variations in $\mathrm{P}_{\mathrm{n}}, \mathrm{g}_{\mathrm{s}}$, and $\mathrm{E}$ among the four individual plants of vinca. The maximum $\mathrm{P}_{\mathrm{n}}$ of dusty miller and that of plumbago were similar. The $P_{n}$ and $g_{s}$ of petunia at $40{ }^{\circ} \mathrm{C}$ were $25 \%$ and $10 \%$ of that at $20{ }^{\circ} \mathrm{C}$ respectively. In contrast, agastache and ornamental pepper had the least decreases in $P_{n}$ and $g_{s}$ as temperature increased. The pattern of $\mathrm{E}$ of petunia in response to temperature was different from the other species; it increased in the temperature range of 20 to $30{ }^{\circ} \mathrm{C}$, but decreased as temperature further increased. This may indicate that petunia plants were severely heat stressed at higher temperatures.

Although petunia had the highest $P_{n}$ among the tested species, its $P_{n}$ and $g_{s}$ declined rapidly as temperature increased from 25 to $40^{\circ} \mathrm{C}$. At $40{ }^{\circ} \mathrm{C}, \mathrm{g}_{\mathrm{s}}$ of petunia was the lowest. This may indicate that petunia was heat sensitive and responded to heat by closing its stomata. In another separate experiment with the same plant species (unpublished data), diurnal course of $F_{v} / F_{m}$ (an indicator of photosystem II efficiency), which was measured six times daily from early morning to late afternoon, showed that petunia had the largest depression in $\mathrm{F}_{\mathrm{v}} / \mathrm{F}_{\mathrm{m}}$ in the mid afternoon among the tested bedding plant species, when the plants were grown in the flower beds in the field with maximum air temperature at around $40{ }^{\circ} \mathrm{C}$. The variable to maximum fluorescence ratio $F_{v} / F_{m}$ is used to detect stress-induced perturbations in photosynthetic apparatus (Baker and Rosenqvist, 2004). Agastache and ornamental pepper had the lowest depression in $\mathrm{F}_{\mathrm{v}} / \mathrm{F}_{\mathrm{m}}$, followed by vinca and plumbago. Therefore, the rapid decreases in $P_{n}$ and $g_{s}$ of petunia in response to temperature increase and decrease of substrate moisture content may indicate that it is less tolerant to heat and drought stresses.

When plants are drought stressed, stomata close progressively, decreasing $g_{\mathrm{s}}$ and hence resulting in reduced rates of transpiration and photosynthesis (Tezara et al., 1999). The response of growth to drought stress depends on the duration and degree of drought stress. Under mild drought stress, leaf area and plant height may be reduced, whereas under severe stress. plant metabolism and other physiological function will be impaired (Huang and Jiang, 2001). Our results on gas exchange of the tested bedding plant species' response to drought stress and heat indicate the relative 

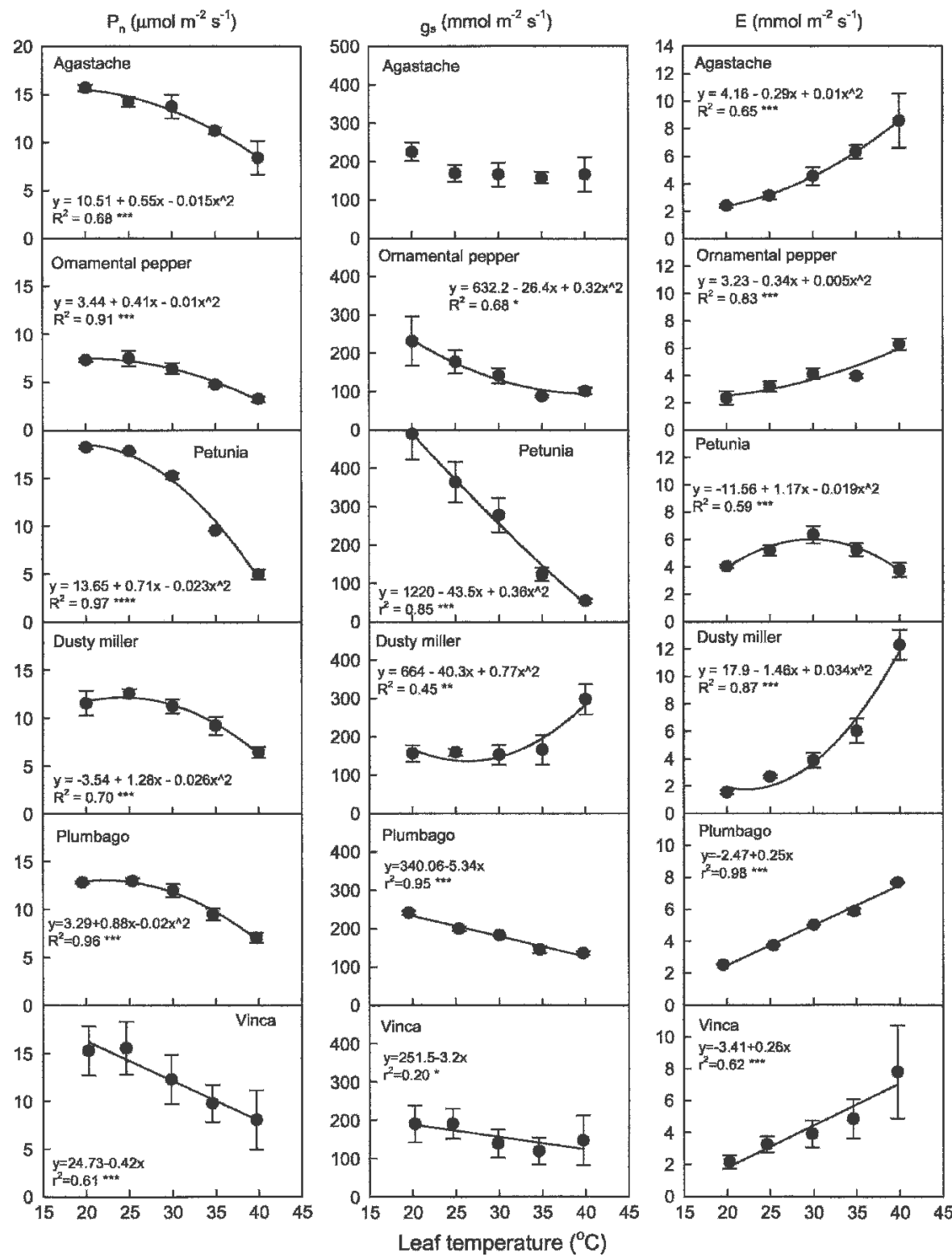

Fig. 2. Leaf net photosynthetic rate $\left(\mathrm{P}_{\mathrm{n}}\right)$, stomatal conductance $\left(\mathrm{g}_{\mathrm{s}}\right)$, and transpiration $(\mathrm{E})$ of agastache (Agastache urticifolia 'Honeybee Blue'), dusty miller (Cineraria maritima 'Silverdusty'), petunia (Petunia $\times$ hybrida 'Wave Purple'), plumbago (Plumbago auriculata 'Escapade'), ornamental pepper (Capsicum annuum 'Black Pearl'), and vinca (Catharanthus roseus 'Titan') in response to increasing leaf temperature. In each graph, $*, * *$, and $* * *$ indicate significance of the linear or quadratic regression at $P=$ $0.05,0.01$, or 0.001 respectively. Vertical bars represent $\operatorname{SE}(\mathrm{n}=4)$. No significance was observed between $\mathrm{g}_{\mathrm{s}}$ and leaf temperature for agastache; therefore, no regression equation is presented.

tolerance among the species. The information generated in this greenhouse study may be used as a reference for further investigating the adaptability and performance of these plant species in the landscapes in warm to hot climates in the future. Because different cultivars perform differently in response to drought and heat stresses, the information presented here is valid only for the cultivars used in this study.

\section{Literature Cited}

Abrams, M.D., M.E. Kubiske, and K.C. Steiner. 1990. Drought adaptations and responses in five genotypes of Fraxinus pennsylvanica Marsh.: Photosynthesis, water relations and leaf morphology. Tree Physiol. 6:305-315.

Anyia, A.O. and H. Herzog. 2004. Water-use efficiency, leaf area and leaf gas exchange of cowpeas under mid-season drought. Eur. J. Agron. 20:327-339.

Baker, N.R. and E. Rosenqvist. 2004. Applications of chlorophyll fluorescence can improve crop production strategies: An examination of future possibilities. J. Exp. Bot. 55:1607-1621.

Ball, V. 1998. Ball redbook. 16th ed. Ball Publishing, Batavia, Ill.

Burnett, S.E., S.V. Pennisi, P.A. Thomas, and M.W. van Iersel. 2005. Controlled drought affects morphology and anatomy of Salvia splendens. J. Amer. Soc. Hort. Sci. 130:775781.

Ennahli, S. and H.J. Earl. 2005. Physiological limitations to photosynthetic carbon assimilation in cotton under water stress. Crop Sci. 45:2374-2382.

Epron, D., E. Dreyer, and N. Breda. 1992. Photosynthesis of oak trees [Quercus petraea(Matt.) Liebl.] during drought under field conditions: Diurnal course of net $\mathrm{CO}_{2}$ assimilation and photochemical efficiency of photosystem II. Plant Cell Environ. 15:809-820.

Hsiao, T.C. and E. Acevedo. 1974. Plant responses to water deficits, water use efficiency, and drought resistance. Agr. For. Meteorol. 14: $59-84$.

Huang, B. 2004. Recent advances in drought and heat stress physiology of turfgrass: A review. Acta Hort. 661:185-192.

Huang, B. and Y. Jiang. 2001. Physiological and biochemical responses of plants to drought and heat stress, p. 287-300. In: M. Kang (ed.). Crop improvement: Challenges in the twenty-first century. Haworth Press, New York.

Ranney, T.G., F.A. Blazich, and S.L. Warren. 1995. Heat tolerance of selected species and populations of rhododendron. J. Amer. Soc. Hort. Sci. 120:423-428.

Ranney, T.G. and J.M. Ruter. 1997. Foliar heat tolerance of three holly species (Ilex spp.): Responses of chlorophyll fluorescence and leaf gas exchange to supraoptimal leaf temperatures. J. Amer. Soc. Sci. 122:499-503.

Stafne, E.T., J.R. Clark, and C.R. Rom. 2000. Leaf gas exchange characteristics of red raspberry germplasm in a hot environment. HortScience $35: 278-280$

Tezara, W., V.J. Mitchell, S.D. Driscoll, and D.W. Lawlor. 1999. Water stress inhibits plant photosynthesis by decreasing coupling factor and ATP. Nature 401:914-917.

van Iersel, M. 1997. Root restriction effects on growth and development of salvia (Salvia splendens). HortScience 32:1186-1190.

U.S. Department of Agriculture. 2005. Floriculture crop 2004 summary. U.S. Dept. Agr. Washington, D.C. 